\title{
Dynamika rozwoju współczesnego języka słowackiego - aspekt gramatyczny
}

\author{
The dynamics of the development of the contemporary \\ Slovak language - grammatical context
}

\author{
Sylwia Sojda \\ Wydział Filologiczny, Uniwersytet Śląski, \\ ul. Grota-Roweckiego 5, 41-205 Sosnowiec, Polska; \\ e-mail: sylwia.sojda@us.edu.pl
}

\begin{abstract}
Abstrakt
Celem szkicu jest wskazanie najważniejszych mechanizmów dynamiki współczesnego języka słowackiego, do których należą: substytucja, multiplikacja i redukcja oraz zauważalne tendencje rozwojowe w podsystemie morfologicznym i syntaktycznym. Najszybciej na zmiany społeczno-polityczne reaguje słownictwo, najwolniej składnia języka. Na poziomie morfologicznym największą dynamikę przejawia deklinacja rzeczowników rodzaju męskiego. Wspólną cechą zmian w omówionych podsystemach jest tendencja do ekonomizacji języka przejawiająca się $\mathrm{w}$ upraszczaniu, unifikacji i regularności form, zmniejszeniu liczby form sekundarnych oraz eliptyczność.
\end{abstract}

Słowa kluczowe: dynamika języka; substytucja; multiplikacja; redukcja; podsystemy językowe.

\begin{abstract}
The aim of this study is to identify the most important mechanisms of the dynamics of the contemporary Slovak language including substitution, multiplication and reduction and noticeable trends in the morphological and syntactic subsystems. Vocabulary tends to be the part of language reacting to social and political changes the fastest. Syntax, on the other hand, is the slowest. On the morphological level, declension of masculine nouns enjoys the highest growth rate. The changes in the discussed subsystems are all leaned towards language economization which manifests itself in simplification, unification and regularity of the forms, reducing the number of secondary forms and ellipsis.
\end{abstract}

Keywords: language dynamics; substitution; multiplication; reduction; language subsystems.

Charakterystyka każdego systemu językowego wymaga uwzględniania wszystkich relewantnych czynników wewnątrzjęzykowych i pozajęzykowych. Ponieważ człowiek jest nosicielem i twórcą języka, zmiany w życiu człowieka i w życiu społeczeństwa znajdują swoje odzwierciedlenie w zmianach w języku - elemencie tożsamości kulturowej i narodowej. Rzeczywistość początku XXI stulecia charakteryzuje się szeroko pojętą globalizacją, modernizacją oraz szybkim rozwojem informatyzacji i elektronizacji, z którą ściśle związana jest mediatyzacja, odznaczająca się intensywnym wpływem i ingerencją mediów we 
wszystkie dziedziny życia, w tym również wpływem na język. Procesom tym podlega także język słowacki, którego zmiany są przedmiotem niniejszego szkicu.

Wpływ na rozwój i postać współczesnego języka słowackiego miały także skomplikowane i zawiłe pod względem historycznym losy narodu słowackiego. Proces kształtowania się literackiego języka słowackiego (spisovná slovenčina) z perspektywy lingwistycznej, zapoczątkowany kodyfikacją z 1843 roku, trwa nieustannie aż po czasy współczesne i można w nim wyodrębnić kilka ważnych etapów. Przemiany języka były opisywane szczególnie w latach 50. i 60. ubiegłego wieku, kiedy organizowano znaczące konferencje naukowe o problematyce językoznawczej i powstawały istotne dla lingwistyki słowackiej opracowania naukowe poszczególnych systemów języka. Istotnym momentem rozwoju języka słowackiego był również rozpad Federacji Czechosłowackiej i powstanie w 1993 roku odrębnego państwa. Na kształt współczesnego języka słowackiego miały niewątpliwie wpływ uwarunkowania polityczne, społeczne i ekonomiczne towarzyszące zmianom ustrojowym na początku lat 90 . XX wieku. Każdy etap rozwojowy języka potwierdza tezę o procesualności systemu językowego (Krajčovič 1985: 76). Jak konstatuje Ján Kačala,

V samom systéme spisovnej slovenčiny nemožno za obdobie po r. 1989 so zretel'om na jeho krátkost' konšatatovat' výraznejšie i pozoruhodnejšie zmeny. Celkove tento krátky úsek možno charakterizovat' ako obdobie, v ktorom vo vývine spisovnej slovenčiny prevážajú pozitívne tendencie $\mathrm{z}$ predchádzajúcich vývinových etáp, ale v dôsledku nižšej i nízkej uvedomenosti niektorých jednotlivcov možno v upotrebúvaní spisovnej slovenčiny v rozmanitých aj celospoločensky závažných oblastiach jazykovej praxe badat' aj uvol'nenie a nedisciplinovanost'. Slovenčina sa však vyvíja za optimálnych spoločenských a politických podmienok s oficiálnou podporou štátu a jeho orgánov, pričom táto podpora je garantovaná zákonom (2010: 83).

Pojęcie dynamiki języka obejmuje kilka zagadnień, których kompleksowy opis pozwala na objęcie szerszą perspektywą licznych zmian w poszczególnych podsystemach współczesnego języka słowackiego. System językowy charakteryzuje się zdolnością do akomodacji, co oznacza przystosowywanie się do otaczającej rzeczywistości w taki sposób, że sam ulega zmianom, utrzymując jednocześnie stan równowagi: nie dopuszcza tylu zmian, które powodowałyby osłabienie języka, a jedynie taką ich liczbę, która jest konieczna do jego prawidłowego funkcjonowania. Jak podkreśla Juraj Dolník, opis zmian językowych połączony jest $\mathrm{z}$ odpowiedzią na podstawowe pytania o istotę procesów dynamicznych: jaki mechanizm rządzi zmianami językowymi?; co jest ich przyczyną?; czy zmiany językowe podlegają ustaleniom o charakterze prawnym? (por. Dolník 2010: 67). Opisując dynamikę języka zwraca się zatem uwagę na realizację stopniowych (zamierzonych i niezamierzonych/spontanicznych) zmian elementów językowych (ich funkcji i norm) oraz stosunków pomiędzy tymi elementami. Zmienność ta ma charakter ciągły, bez względu na zakres czasowy lub liczbę konkretnych zmian. I wreszcie, dynamika języka to opis wariantywności zjawisk językowych 
zachodzących w czasie. L’ubomír Kralčák podsumowuje, że „dynamika jazyka je jeho variantnost' v čase" (2010: 460).

Motywacja zmian językowych może mieć różną specyfikację, a efekt jej różnorodności wynika z nierównomiernego rozkładu na poszczególnych poziomach języka. Motywacja tendencji rozwojowych w fonetyce i gramatyce ma charakter głównie wewnątrzjęzykowy, rzadziej pozajęzykowy. Z drugiej strony, zmiany rozwojowe w leksyce wskazują na tło socjokulturowe, stąd ich motywacja ma w przeważającej mierze charakter pozajęzykowy. Z punktu widzenia systemu językowego mechanizmy dynamizujące język obejmują transformacje poszczególnych jego elementów, a z perspektywy stosunku formy i funkcji można wyróżnić trzy typy zmian obejmujących procesy zachodzące w systemie językowym: zmianę formalną, funkcyjną i kompleksową (funkcyjno-formalną) (Kralčák 2010: 460-461). We współczesnym językoznawstwie słowackim, które opisuje język jako system otwarty, wyróżnia się trzy ogólne mechanizmy procesów dynamicznych (por. Kralčák 2010: 462). Należą do nich:

- substytucja (zastępowanie), która realizuje się przede wszystkim jako zmiana formalna uwidoczniona na poziomie wyrazu. Jest to mechanizm bezpośredniego zastępowania form elementów pierwotnych nowymi formami ekwiwalentnymi lub formami wcześniej istniejącymi w systemie. Dana forma jest podstawowa dla pewnego znaczenia, ale istnieją jednocześnie inne ustalone wariantywne możliwości wyrażenia leksemu. Substytucja formalna zakłada z jednej strony akwizycję nowej formy (ewentualnie rozszerzenie polifunkcyjności formy już istniejącej), $\mathrm{z}$ drugiej natomiast obejmuje zanik formy pierwotnej. Substytucje formalne dotyczą najczęściej warstwy leksykalnej języka, zastępowanie leksemu jest bezpośrednio związane z jego depozycją, czyli przesunięciem kwalifikacji leksemu na osi aktualny - przestarzały - archaiczny. Drugi rodzaj substytucji - substytucja funkcyjna oznacza zmianę funkcji środka językowego przy jednoczesnym zachowaniu jego formy i rozszerzaniu znaczenia (w przypadku leksyki chodzi o neosemantyzację). Przykładem substytucji jest zanik formy przypadkowej wołacza w języku słowackim i w konsekwencji przejęcie jego funkcji przez mianownik, który tym samym rozszerzył swoją polifunkcyjność (funkcja zwracania się do innej osoby: otec, pan);

- multiplikacja, polegająca na pomnażaniu elementów formalnych i funkcyjnych w języku. Multiplikację egzemplifikują innowacje rozszerzające, które dotyczą, podobnie jak w wymienionym wyżej procesie, głównie warstwy leksykalnej, np. powstawanie nowych tworów językowych w języku słowackim z czasów L’udovíta Štúra określających nowe denotaty: novináreň 'redakcia', zapisuvatel 'notár', tajomňik 'sekretár';

- redukcja, oznaczająca ubywanie, wypadanie elementów językowych (ich funkcji i/lub formy) bez zastępowania ich innymi. Na płaszczyźnie morfologicznej proces ten ilustruje formalny zanik morfemów je(st) oraz sú w 3. osobie liczby pojedynczej i mnogiej czasu przeszłego. Z wcześniejszych form prišiel je(st) i prišli sú pozostały formy proste prišiel, prišli, w których nieobecność formalna 
morfemu gramatycznego (zero morfologiczne), przy jednoczesnym zachowaniu innych morfemów w pozostałych formach czasu przeszłego (som, si, sme, ste) ma funkcję ograniczoną do wyrażania gramatycznego znaczenia liczby (pojedynczej lub mnogiej) i osoby (trzeciej), czyli identyczną z funkcją zredukowanych morfemów.

Zmiany zachodzące w języku naturalnym mają niewątpliwie wpływ na skuteczność komunikacji międzyludzkiej. Kultura komunikacji, z kolei, ma związek z przestrzeganiem normy. We współczesnym języku słowackim za normę uważa się zbiór zasad mających siłę regulacyjną, które ukierunkowują zachowanie człowieka. Stanowi zatem bardziej propozycję niż sztywne reguły, a w ich obrębie wyróżnia się normy systemowe, mowne (rečové) odnoszące się do czynników wewnątrzjęzykowych i pozajęzykowych, oraz komunikacyjno-sytuacyjne. Normy językowe mają formę skodyfikowaną, normy komunikacyjne są natomiast niekodyfikowane i zbliżone w pewnym stopnia do uzusu językowego. Juraj Dolník określa go jako zbiór nawyków członków społeczeństwa, które uważają za odpowiednie i powszechnie ich używają. Nawyki te dotyczą również elementów nieskodyfikowanych, niewłaściwych (nespisovných) (por. Dolník 2010: 98-105). Badania socjolingwistyczne nad słowackim uzusem językowym, przeprowadzone w latach 90. ubiegłego wieku, pokazały jego złą kondycję, która charakteryzuje się nasyceniem anglicyzmami i bohemizmami oraz dużą liczbą błędnych konstrukcji.

Współczesna komunikacja opiera się na teorii języka literackiego i wywodzi się z założenia, że jeśli uczestnicy komunikacji respektują normy językowe i komunikacyjne, są równorzędnymi partnerami, funkcjonuje mechanizm zmiany kodów, osiągnięcie celu komunikacyjnego nie stanowi problemu (Klincková 2010: 468-469). Aspekt gramatyczny języka dotyczy w tym opracowaniu podsystemu morfologicznego i składniowego; jego reguły pozwalają na wytwarzanie (gramatycznie) poprawnych wypowiedzeń. W lingwistyce słowackiej w obrębie podsystemu morfologicznego znajduje się fleksja, natomiast słowotwórstwo wchodzi w skład leksykologii. Stąd też przedmiotem zainteresowania stają się tutaj zmiany zachodzące w strukturach morfologicznych i fleksyjnych, a przeobrażenia fonetyczne zostaną jedynie zasygnalizowane.

\section{Podsystem fonetyczno-fonologiczny}

Najniższa płaszczyzna języka, płaszczyzna fonetyczno-fonologiczna, analizowana w krótkim odstępie czasowym, sprawia wrażenie stosunkowo stałej. Jej przemiany są stopniowe, a całkowity czas potrzebny do przeprowadzenia zmiany fonetycznej to co najmniej 75 lat, czyli okres, w którym zmieniają się trzy pokolenia użytkowników języka. Dzieje się tak, ponieważ mechanizmy artykulacyjne przyswajane są w sposób naturalny, a ogólniejsza fonologiczna interpretacja dźwięków mowy, identyfikacja różnych ich realizacji w postaci fonemu (z jego allofonami i wariantami) jest w proce- 
sie naturalnego przyswajania języka zależna właśnie od tej rzeczywistości dźwiękowej i jej zastosowania w komunikacji (Krčmová 2005: 76).

Charakterystyczne dla współczesnego języka słowackiego jest intensywne przejmowanie leksemów z języka angielskiego i właśnie w wymowie tych wyrazów dostrzega się najwyraźniejsze zmiany. Odzwierciedlają one stopień adaptacji zapożyczeń z języka angielskiego do języka słowackiego poprzez wymowę angielską: know-how [nouhau], puzzle [pazl], outsourcing [autsorsing] lub ,mieszaną" angielsko-słowacką: część leksemu wymawiana jest po słowacku, część po angielsku, np. workshop [vorkšop], last minute [lást minit], all inclusive [ól inkluziv]. W leksemach zaadaptowanych (również graficzne) do słowackiego systemu leksykalnego nastąpiło całkowite ,zesłowacczenie” wymowy, np. víkend (z ang. weekend), tím (z ang. team), kouč (z ang. coach). Inną wartą uwagi kwestią dotyczącą zmian w podsystemie fonetycznym jest zaniedbywanie przez użytkowników języka słowackiego wymowy miękkiego l': l'an [lan], l’ad [lad], l’udia [ludia], hl'adisko [hladisko].

\section{Podsystem morfologiczny}

Badania (o charakterze deskryptywno-lingwistycznym, socjologicznym oraz w obrębie morfologii eksplanacyjnej) nad dynamiką podsystemu morfologicznego współczesnego języka słowackiego w ostatnim półwieczu opierają się na poszukiwaniach odpowiedzi na następujące pytania (Dolník 2010: 78):

1. Które innowacje/zmiany umacniają się w podsystemie morfologicznym?

2. Jak przejawiają się owe innowacje z perspektywy zróżnicowania użytkowników języka słowackiego?

3. Jak można te zmiany wyjaśnić?

W dotychczasowej lingwistyce słowackiej przeważają prace, które mogą udzielić odpowiedzi na pierwsze z postawionych pytań. Rezultatem zadań deskryptywno-lingwistycznych jest wyczerpujący opis synchronicznych zjawisk językowych zachodzących w podsystemie morfologicznym w postaci inwentaryzacji tych zjawisk, charakteryzowania ich z perspektywy kontynuacji historycznego rozwoju morfologicznego języka słowackiego oraz formułowania wniosków o tendencjach zmian i wreszcie - upowszechnianie badań synchronicznych poprzez umiejscowienie ich w obrębie badań empirycznych. Mniejszym stopniem zaawansowania charakteryzują się badania socjolingwistyczne mające odpowiedzieć na drugie z wyżej wymienionych pytań. Istotą podejmowanych rozważań w aspekcie socjolingwistycznym jest opisanie i interpretacja realnego stanu innowacji morfologicznych, tzn. wskazanie na ich rzeczywiste występowanie w języku używanym przez zróżnicowane społeczeństwo. Znaczącą składową tego typu badań jest ponadto praktyczna weryfikacja założeń kodyfikacyjnych języka słowackiego mająca na celu ich optymalizację. Najmniej rozwinięte są badania w obrębie morfologii eksplanacyjnej, opartej na wynikach badań deskryptywno-lingwi- 
stycznych, empirycznych oraz ogólnych wnioskach odnoszących się do tendencji rozwojowych. Metodologia morfologii eksplanacyjnej opiera się na założeniach, które prowadzą do wyjaśnienia, z czego wypływają innowacje morfologiczne oraz jakie są ich zasady.

Najbardziej zauważalną zmianą w dynamice synchronicznej współczesnego języka słowackiego jest umacnianie się zmian wewnątrz paradygmatów, czyli zmian pojawiających się pod wpływem elementów tego samego paradygmatu oraz zmian związanych z przemieszczaniem się międzyparadygmatycznym. Chodzi o działanie analogii, czyli zasady wyrównywania form (Dolník 2010: 79). Egzemplifikacjami tych procesów są zmiany w obrębie tematu i zmiany w obrębie formantów ${ }^{1}$.

1. Zmiany w obrębie tematu:

a. zachowanie obcych sufiksów w dopełniaczu liczby pojedynczej na wzór leksemów rodzimych zgodnych z paradygmatem rzeczowników żywotnych rodzaju męskiego chlap-ø, np. Feidi-as - Feidi-a/Feidi-as-a; Sizyf-os - Sizyf-a/Sizyf-os-a, Sofokl-es - Sofokl-a/Sofokl-es-a;

b. usuwanie alternacji w nazwiskach rodzimych zakończonych na -ec, -ek, -ok, -er, -el: Korec - Korca/Koreca, Mlacek - Mlacka/Mlaceka, Samec - Samecal Samca;

c. w dopełniaczu liczby mnogiej rzeczowników rodzaju nijakiego (wzór mesto) i żeńskiego (wzory žena, ulica) następuje wzdłużenie ostatniej sylaby tematu (upodabniając do głównych leksemów tego paradygmatu) za pomocą dyftongu -ie: číslo-čísel/čisiel; písmeno-pismen/pismien; účastnićka-účastníčok/ účastnićiek;

d. tendencja do unifikacji rzeczowników z paradygmatu rodzaju nijakiego wzoru dievča $\mathrm{z}$ elementem -at- w mianowniku liczby mnogiej: dievčence/dievčatá, štence/štenatá, kurence/kurčatá.

2. Zmiany w obrębie formantów:

a. wzmacnianie formantu $-i$ wśród konkurencyjnych formantów -ovia/-i w mianowniku liczby mnogiej rzeczowników rodzaju męskiego należących do paradygmatów chlap i hrdina: stenografi/stenografovia; lexikografi/lexikografovia; posli/poslovia; záujemci/záujemcovia;

b. wzmacnianie formantu $-u \mathrm{w}$ dopełniaczu liczby pojedynczej rzeczowników rodzaju męskiego z paradygmatu dub: Śtokholmu/Štokholma;

c. tendencja do wyrównania paradygmatów rzeczowników rodzaju żeńskiego odmienianych według wzoru ulica z paradygmatem kost'w dopełniaczu liczby pojedynczej: Soňa - Sone/Soni; Bystrica - Bystrice/Bystrici;

d. tendencja do wyrównania paradygmatów rzeczowników rodzaju żeńskiego odmienianych według wzoru kost' z paradygmatem dlan̆ (postulowane jest dopuszczanie dwóch form) w dopełniaczu liczby pojedynczej: mlad' - mladel mladi; mysel' - mysle/mysli; raž - raže/raži; tvár - tváreltvári. Analiza rze-

1 Opracowane na podstawie prac: Dolník 2010, Považaj 2008. 
czowników należących do paradygmatu kost' i dlan̆, którą przeprowadził Považaj (2008: 404) wskazuje na przechodzenie rzeczowników z pierwszego paradygmatu do drugiego, jednak nie jest to proces tak intensywny, jak to miało miejsce w pierwszej połowie XX wieku. W konsekwencji,

konštatovanie o neproduktívnosti skloňovacieho vzoru kost'publikované vo viacerých starších prácach nezodpovedá úplne skutočnosti, lebo vychádzalo iba z toho, že v istom období vývinu súčasnej spisovnej slovenčiny nastal výraznejší presun substantív od vzoru kost' k vzoru dlan̆, nie z toho, kol'ko substantív sa skloňuje podl'a týchto vzorov, ako na to už upozornili niektorí autori. Vzor kost'sa aj v súčasnosti obohacuje o mnohé nové substantíva utvorené produktívnou slovotvornou príponou -ost', lebo ide o živý slovotvorný postup. Na druhej strane vzor dlan̆ sa sústavne obohacuje o nové substantíva utvorené produktívnou slovotvornou príponou -áreň a jej variantnými príponami -areň, -iareň (Považaj 2008: 414).

e. tendencja do wyrównania paradygmatów rzeczowników rodzaju nijakiego odmienianych według wzoru srdce $\mathrm{z}$ paradygmatem vysvedčenie $\mathrm{w}$ narzędniku liczby mnogiej: more - morami/moriami; pole - pol'ami/poliami;

f. rozszerzanie morfemu $-a \mathrm{w}$ dopełniaczu i bierniku liczby pojedynczej rzeczowników z paradygmatu chlap na rzeczowniki w paradygmacie hrdina: Hečko - Hečka/Hečku; Lenko - Lenka/Lenku; Ferko - Ferka/Ferku;

g. wzbogacanie paradygmatu rodzaju męskiego kuli rzeczownikami/nazwiskami zakończonymi na -e, -ě, - $i,-i$ należącymi wcześniej do paradygmatów rzeczownikowych chlap, hrdina lub paradygmatu przymiotnikowego cudzí: Purkyně - Purkyněho; Clemente - Clementeho; Dolejši - Dolejšiho;

h. stopniowe ustępowanie morfemu zerowego w dopełniaczu liczby mnogiej rzeczowników rodzaju męskiego z paradygmatów dub i stroj, w którego miejscu umacnia się sufiks -ov: Tovarniky - Tovarnik/Tovarnikov; Tlmače - Tlmáč/Tlmačov; Vráble-Vrábel'/Vráblov;

i. zbliżenie fleksji przymiotników dzierżawczych z paradygmatu otcov do paradygmatu pekný: otcov - otcova/otcová/otcovu/otcovú;

j. rozszerzenie znaczenia formantu -ost' (z pierwotnego, służącego do tworzenia nazw właściwości) na leksemy wyrażające ilość: rozvodovost' ('liczba rozwodów w ciągu roku w kraju'); úmrtnost' ('liczba zgonów w ciągu roku');

k. występowanie konkurencyjnych morfemów relacyjnych -iam,-iach w celowniku i miejscowniku liczby mnogiej rzeczowników rodzaju żeńskiego z paradygmatów ulica i dlan̆: dielňa - dielňach/dielniach; báseñ - básňam/básniam/ básňach/básniach;

1. wzdłużanie morfemu gramatycznego po $j \mathrm{w}$ rzeczownikach rodzaju żeńskiego z paradygmatów ulica i dlaň: alej-alejam/alejám/alejach/alejách; esej-esejam/esejám/esejach/esejách;

m. wzmocnienie pozycji imiesłowu biernego zakończonego na -tý: natrený/natretý; zamdlený/zamdletý; natrený/natretý.

Podsumowując zmiany zachodzące w podsystemie morfologicznym współczesnego języka słowackiego, należy skonstatować, że przeważa tendencja do 
upraszczania form, unifikacji tematu i formantów oraz kompaktywność paradygmatów. Tendencja do systemowości postępuje w kierunku udomowienia leksemów obcego pochodzenia poprzez przyjmowanie przez nie form rodzimych, charakterystycznych dla języka słowackiego. Opisane zmiany postępują szybciej niż zmiany w podsystemie syntaktycznym.

\section{Podsystem składniowy}

Podsystem składniowy jest płaszczyzną języka najwolniej reagującą na zmiany. Ma to niewątpliwie związek z jej najwyższym stopniem systemowości i trwałości. Jedną z najwyraźniejszych tendencji obserwowanych w obrębie płaszczyzny syntaktycznej jest tendencja do ekonomizacji. Wyraźną zmianą zatem, zauważalną już na początku XX wieku, było upraszczanie skomplikowanych struktur składniowych w tekstach stylu naukowego, administracyjnego i publicystycznego (długość zdania uległa w nim skróceniu głównie w tekstach sprawozdawczych, co związane było z silną tendencją do ekonomizacji przekazu). Do głównych zmian zauważalnych w słowackim podsystemie składniowym należą:

a. upraszczanie wypowiedzeń wielokrotnie złożonych do zdań pojedynczych za pomocą substantywizacji obiektu: KSS uvažuje o kúpe straníckej budovy; Nemci potvrdili hrozbu porušenia pravidiel únie;

b. nadużywanie przydawki niekongruentnej w dopełniaczu, co może powodować problem ze zrozumieniem tekstu publicystycznego: $Z$ pohl'adu únie nehrozi zo strany Holandska kvôli predčasným vol’bám oneskorenie jej rozširenia;

c. ekonomizacja w wypowiedzeniach należących do stylu potocznego wyrażająca się eliptycznością i rozbijaniem zdań na mniejsze, jakby niepowiązane części, często wiążąca się ze zmianą modalności: Vyjadrujeme vám svoju úprimnú sústrast'Prijmite našu úprimnú sústrast'.

Przeobrażenia składniowe współczesnego języka słowackiego wypływały ze zmian obserwowanych w morfologii, w głównej mierze w obrębie fleksji (przede wszystkim) rzeczownikowej. I tak, na podstawie analiz systemu językowego zawartych w znaczących słowackich opracowaniach normatywnych (mamy tu na myśli głównie takie opracowania, jak: Štruktúra slovenského slovesa 1943, Morfológia slovenského jazyka 1966, Väzba slovies v slovenčine 1967, Slovenská gramatika 1968) lingwiści doszli do następujących wniosków dotyczących dynamiki podsystemu syntaktycznego:

a. mianownik (nominativ) jest przypadkiem nazywającym, który prymarnie spełnia funkcję aktywnego subiektu - wykonawcy czynności, natomiast sekundarnie służy do wyrażenia nieaktywnego uczestnika - nosiciela czynności. Zauważa się ponadto funkcję mianownika jako wariantywnego orzecznika w orzeczeniu imiennym, np. Adam je voják;

2 Opracowane na podstawie prac: Tibenská 2005, 2012; Horváth 2014. 
b. dopełniacz (genitív) służy do wyrażania przydawki niekongruentnej - funkcja ta uległa wzmocnieniu, m.in. w konkurencji z przymiotnikami dzierżawczymi, np. To je Evina izba/To je izba Evy; Obdivujem ženskú krásu/Obdivujem krásu ženy;

c. celownik (dativ) (z przyimkiem lub bez przyimka) wyraża obiekt jako adresata czynności: Prezident sa prihovoril národu, podczas gdy przed siedemdziesięcioma laty funkcję tę spełniał biernik, np. prehovorit' na niekoho;

d. biernik (akuzatív) pełni funkcję nieaktywnego obiektu - patiensa oraz nieaktywnego subiektu - nosiciela stanu: Deti si ctia svojich rodičov; Trasie ho od zimy. Nastąpiło wzmocnienie formy biernikowej, co uwidaczniają egzemplifikacje: pýtat' o radu/pýtat' radu; zabudol o mne/zabudol na mňa; mysliet'o nie$\mathrm{kom} / \mathrm{mysliet}$ na niečo; neviazat' sa $k$ téme/neviazat' sa na tému. Inną zauważalną tendencją jest używanie biernika w miejsce dopełniacza partytywnego: nalovit' rybu, navarit' polievku, premiešat múku (nalovit' vel'a rýb, navarit' mnoho polievky, premiešat' trochu múky);

e. forma bezprzyimkowego narzędnika (inštrumentál) stała się prymarną formą morfologiczną dla wyrażania narzędzia/środka: záhrada zarástla búrinou; obilie zakvitá červeným makom; otvoril dvere klúčom. Zauważalne jest również zastępowanie dopełnienia wyrażanego miejscownikiem z przyimkiem $p o$ formą narzędnikową z przyimkiem za: pachtit'sa po niečom/pachtit'sa za niečom oraz rzadsze używanie narzędnika jako składowej orzeczenia imiennego: Adam je vojákom;

f. miejscownik (lokál) służy do wyrażania okolicznika: Prídeme o druhej hodine v noci; Kniha je v polici; Dom sa nachádza na konci ulice, ale może też pełnić funkcję przydawki niekongruentnej: pozerali sme film o Ježišovi, čítali sme rozprávku o Červenej čiapočke.

Do innych zauważalnych zmian w obrębie płaszczyzny syntaktycznej należą:

a. wzmacnianie się uniwersalnej pozycji spójników hipotaktycznych že, čo, co skutkuje ich nieuzasadnionym nadużywaniem;

b. uproszczenie składni zdania pojedynczego i złożonego;

c. rzadsze używanie prechodníka (imiesłów przysłówkowy współczesny) - zastępowanie go formą czasu przeszłego, np. Robiac úlohu počúval hudbu-Ked' robil úlohu, počúval hudbu;

d. kontaminacja, np. 35 miliárd dolárov, to je výška zahraničnej pomoci, ktorú bude krajina potrebovat'v tomto a na budúci rok (poprawnie: $v$ tomto roku a na budúci rok); Stovky tamojšich drevených stavieb sú považované za vzácne dôkazy (poprawnie: stovky drevených stavieb je považovaných);

e. błędna rekcja przyimkowa, np. Je podozrivý z niekol'komilionóvej sprenevery (peñazi) z nadácie (poprawnie: $v$ nadácii).

Podsumowując obserwacje dotyczące podsystemu składniowego współczesnego języka słowackiego, należy konstatować, iż jest on podsystemem najwolniej reagującym na zmiany, charakteryzuje go silniejsza i bardziej długoterminowa tendencja do systemowości, utrwalenia, ubywa postaci wariantywnych (a ich uży- 
wanie ma swoje znaczeniowe podstawy), stosunki składniowe natomiast stają się bardziej przejrzyste.

\section{Podsumowanie}

Wzmożone badania nad słowacką płaszczyzną morfologiczną prowadzone były w latach 60 . i 70. ubiegłego stulecia, natomiast badania składni rozpoczęto w latach 50. XX wieku i zorientowane były na zagadnienia cząstkowe (np. kwestia bezokolicznika, łączliwości czasownika, zdania wielokrotnie złożone). W latach 80. ubiegłego wieku zaczęto stopniowo interesować się strukturą semantyczną wypowiedzenia, a współczesna metodologia obejmuje coraz częściej aspekty socjolingwistyczne.

Na zmiany polityczne, ekonomiczne i społeczne najszybciej reaguje warstwa leksykalna języka, najwolniej zaś poziom składniowy. Na poziomie morfologicznym największy stopień dynamiki wykazuje deklinacja rzeczowników, a w jej obrębie deklinacja rzeczowników rodzaju męskiego. Cechą wspólną zmian następujących w omówionych tu podsystemach jest tendencja do ekonomizacji języka przejawiająca się w upraszczaniu, unifikacji i regularności form, zmniejszenie liczby form sekundarnych oraz eliptyczność.

Patrząc zarówno na podstawowe mechanizmy dynamiki języka, jak i na rezultaty, można wysnuć wniosek, że chodzi przede wszystkim o sposób opisu dynamiki rozwojowej języka, co nie oznacza, że nie można jej rozpatrywać w aspekcie synchronicznym. Spojrzenie synchroniczne na dynamikę języka zakłada bowiem nieskończoność procesów dynamicznych, której wynikiem i bezpośrednim wyrazem jest aktualna wariantywność zjawisk językowych.

\section{Bibliografia}

Dolník J., 2010, Synchrónna dynamika morfológie, w: Morfologické aspekty súčasnej slovenčiny, red. J. Dolník, Bratislava, s. 65-96.

Horváth M., 2014, Aktuálny obraz úrovne jazykovej kultúry v hlavnej správodajskej relácii RTVS/Slovenskej televizie, https://medialnistudia.files.wordpress.com/.../ ms_2014_1_horvath_web [dostęp: 30.03.2014].

Kačala J., 2010, Spisovná slovenčina v 20. storočí, Bratislava.

Klincková J., 2010, Syntax hovorených komunikátov, w: Odkazy a výzvy modernej jazykovej komunikácie, red. J. Klincková, Banská Bystrica, s. 467-485.

Krajčovič R., 1985, Procesuálnost' ako vlastnost' jazykového systému a jej výskum, w: K princípom marxistickej jazykovedy. Materiály z konferencie o marxistickej jazykovede (Smolenice 21. - 23. novembra 1983), red. J. Horecký, Bratislava, s. 76-80.

Kralčák L., 2010, Mechanizmy dynamiky jazyka, w: Slovo - tvorba - dynamickost', red. M. Šimková, Bratislava, s. 460-465.

Krčmová M., 2005, Przemiany warstwy brzmieniowej języka czeskiego, w: Rozwój języka czeskiego po aksamitnej rewolucji, red. M. Balowski, Racibórz, s. 76-85.

Oravec J., 1967, Väzba slovies v slovenčine, Bratislava. 
Pauliny E., 1943, Štruktúra slovenského slovesa, Bratislava.

Pauliny E., Ružička J., Štolc J., 1968, Slovenská gramatika, Bratislava.

Považaj M., 2008, Niektoré dynamické tendencie slovenskej morfológie, w: Jazyk a jazykoveda v pohybe, red. S. Mislovičová, Bratislava, s. 408-415.

Ružička J. (red.), 1966, Morfológia slovenského jazyka, Bratislava.

Tibenská E., 2005, Vývinové tendencie v súčasnej syntaxi, w: Język i literatura słowacka w perspektywie słowiańskiej, red. H. Mieczkowska, B. Suchoń-Chmiel, Kraków, s. $77-85$.

Tibenská E., 2012, Zmeny vjazykových podsystémoch (čiastkových normách): syntaktická rovina, w: E. Tibenská, Slovenčina v zrkadle vnútorných a vonkajšich vztahov, Zagrzeb, s. 11-22. 
